curred between 2 molecules of the tetra-aryl-methane compound, and not within one molecule through the destruction of both phenolic hydroxyl groups.

Diphenyl- $\alpha$-naphthyl Carbinol, $\left(\mathrm{HOC}_{6} \mathrm{H}_{4}\right)\left(\mathrm{C}_{6} \mathrm{H}_{5}\right)\left(\mathrm{C}_{10} \mathrm{H}_{7}\right)$ : C.OH. The fuchsone was dissolved in a small quantity of alcohol and then heated. to boiling with $N$ sodium hydroxide solution until the color of the solution had changed from red-yellow to a very light yellow. This solution was diluted with an equal volume of water and the carbinol was precipitated as a light yellow amorphous material upon the addition of a saturated solution of ammonium chloride. Attempts to recrystallize the carbinol from the common organic solvents were not successful. The method previously employed ${ }^{1}$ for the isolation of the colored and colorless tautomers of a similarly amorphous carbinol was not successful in this case, because of partial dehydration of the carbinol to form the fuchsone when it is dissolved in acetic acid. Whether precipitated from an alkaline solution or from acid solution, the carbinol looks equally intense in color, loses water at about the same rate and readily changes to the fuchsone. However, the sample from dil. acetic acid, presumably quinonoid, begins to soften and turn red at $70^{\circ}$, while the sample from an alkaline solution, and presumably containing some benzenoid carbinol, begins to soften and turn red at $87^{\circ}$.

Thus, it has been demonstrated that a naphthyl group exerts a stronger tautomerizing influence than a phenyl group; also, that in this case as well, similarly to those described in previous papers, the formation of fuchsone is preceded by the intermediate stage, namely, the formation of the quinonoid carbinol.

ANN ARBOR, MICHIGAN.

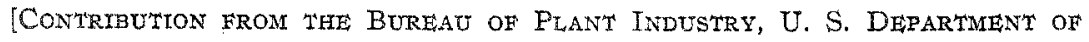
AGRICULTURE.]

\title{
A MOSAIC DISEASE OF CABBAGE AS REVEALED BY ITS NITROGEN CONSTITUENTS. ${ }^{2}$
}

BY S. L. JoDid.

(With the coöperation of S. C. Moulton and K. S. Markley.)

Received June 23, 1920.

\section{Introductory.}

It is generally accepted in plant hygiene that only healthy and vigorous plants, as a rule, yield maximum returns. Hence, it goes without saying that measures looking to the amelioration of our cultivated plants will, of course, lead to crops superior both in quality and quantity. This object may be attained by finding proper remedies for the existing plant

${ }^{1}$ Gomberg and Todd, This Journal, 39, 2392 ( $19 \mathrm{I} 7$ ).

2 Presented before the Division of Biological Chemistry at the Chicago Meeting of the American Chemical Society, September 6m, 10,1920 . 
diseases, on the one hand, and by selecting and breeding improved and immune varieties on the other. However, the fact that the development of improved and disease-resistant varieties through selection and breeding will require very much time and labor and the further consideration that a plant variety immune from one disease is not necessarily immune from other diseases, renders it advisable, if not imperative, along with the cultivation of improved and immune varieties, to study plant diseases with the object in view of finding suitable means for combating the latter.

Though its organs are somewhat modified as storage organs, the cabbage plant (Brassica oleracea) has essentially the important nutritive qualities which a leafy vegetable possesses. Thus, it compares favorably with seeds, roots, and tubers in regard to the content of the inorganic elements, calcium and sodium, ${ }^{1}$ being richer in the water-soluble ${ }^{2}$ vitamine $B$, and containing in addition also the fat-soluble ${ }^{3}$ vitamine $A$. The culture of cabbage for sauerkraut is too well known to dwell here upon this subject. At any rate, the desirable qualities of cabbage as food naturally suggest the necessity of doing away with a disease which is marked by a few symptoms chief among which is dwarfing of the affected plants and change of their color. While the leaves of normal cabbage plants have a healthy green color, those of diseased plants show a yellowish, metallic color between the veins, only the spaces nearest to the veins being green. At the same time the affected leaves are brittle, their margins being frequently of a uniform yellow color. Coupled with this is the comparatively pootly developed root system and the stunting of the diseased plants, all of which leads to poorer crops of inferior quality. Inasmuch as the cabbage disease under consideration has several symptoms in common with the spinach blight described in a previous ${ }^{4}$ paper, the idea suggested itself to apply to this work the methods used in the spinach investigation with certain necessary modifications.

It is a pleasure here to acknowledge the highly appreciated help and cooperation of the Office of Cotton, Truck and Forage-crop Disease Investigations, as well as of the Virginia Truck Experiment Station.

\section{Experimental.}

Twelve perfectly healthy cabbage plants were taken in April, x918, from the Lambert farm at Ocean View Road, Va., to which another dozen of equally normal plant $s^{5}$ secured from the Cooper farm at Norfolk, Va.,

${ }^{1}$ McCollum, Simmonds and Pitz, J. Biol. Chem., 30, I8 (I917).

Osborne and Mendel, ibid., 4r, 456 (1920),

"Ibid., 37, 195 (1919).

" Jodidi, Moulton and Markley, Thus Journat, 42, 106r (1920).

${ }^{5}$ We owe our gratitude to Prof. T. C. Johnson, Director, Virginia Truck Experiment Station, for assistance in selecting the cabbage plants. 
were added. At the same time from 25 to 30 diseased cabbage plants were selected from the Lambert farm. The healthy and diseased plants were separately dried, first at room temperature and finally in an electric drying oven at $50^{\circ}$, to be then powdered, passed through a 40-mesh sieve and transferred to sealed jars.

Description of Methods.-The total nitrogen was determined by Kjeldahl's method modified to include the nitrogen of nitrates.

The ammoniacal nitrogen was estimated according to Grafe's method in vacuo as described in a previous ${ }^{1}$ paper.

The estimation of nitric, nitrous and protein nitrogen was carried out essentially according to the description given in the last mentioned paper.

The proportion of acid amide, humin, basic and non-basic nitrogen was determined according to Hausmann' $\mathrm{s}^{2}$ method as applied by one $\mathrm{e}^{3}$ of us to soil investigations.

Table I-Showing the Proportion of Total Ammoniacal, and Nitrous Nitrogen In the CabBage.

\begin{tabular}{|c|c|c|c|c|c|c|c|c|}
\hline \multirow[b]{2}{*}{$\begin{array}{l}\text { Healthy } \\
\text { cabbage } \\
\text { material. }\end{array}$} & \multirow{2}{*}{$\begin{array}{c}\text { Total } \\
\text { nitrogen. } \\
\text { Oven- } \\
\text { dried } \\
\text { cabbage. } \\
\% \% \\
\%\end{array}$} & \multirow[b]{2}{*}{$\begin{array}{c}\text { Ni- } \\
\text { trites. } \\
\% \%\end{array}$} & \multirow[b]{2}{*}{$\begin{array}{l}\text { Diseased } \\
\text { cabbage } \\
\text { material. }\end{array}$} & \multirow{2}{*}{$\begin{array}{c}\text { Total } \\
\text { nitrogan. } \\
\text { Oven- } \\
\text { dried } \\
\text { cabbage. } \\
\% .\end{array}$} & \multirow[b]{2}{*}{$\begin{array}{c}\text { Nitrites. } \\
\%\end{array}$} & \multicolumn{3}{|c|}{ Ammoniacal nitrogen. } \\
\hline & & & & & & $\begin{array}{l}\text { Oven- } \\
\text { dried } \\
\text { cabbage. } \\
\% .\end{array}$ & $\begin{array}{l}\text { Total } \\
\text { nitro- } \\
\text { gen. } \\
\text { \%. }\end{array}$ & $\begin{array}{l}\text { Soluble } \\
\text { nitro- } \\
\text { gen. } \\
\% \text { \%. }\end{array}$ \\
\hline \multirow[t]{2}{*}{ Leaves......... } & 4.91 & 0.0 & Leaves & 3.72 & Present & 0.180 & 3.75 & $5 \cdot 5 \mathrm{I}$ \\
\hline & 4.86 & 0.0 & $\cdots$ & 3.73 & $\cdots$ & 0.180 & 3.75 & $5 \cdot 5 \pi$ \\
\hline \multirow{4}{*}{ (Sample A)..... } & 4.97 & $\cdots$ & $\ldots \ldots$ & $3.7 I$ & $\cdots$ & .. & $\cdots$ & $\cdots$ \\
\hline & 4.85 & $\ldots$ & (Sample A) & $3 \cdot 74$ & $\cdots$ & $\ldots$ & . & $\cdots$ \\
\hline & 4.8 .5 & $\cdots$ & $\ldots \ldots$ & $3 \cdot 73$ & $\ldots$ & $\ldots$ & $\cdots$ & . \\
\hline & 4.85 & $\ldots$ & $\cdots \cdots$ & 3.75 & $\cdots$ & $\ldots$ & $\ldots$ & . \\
\hline \multirow{3}{*}{$\begin{array}{l}\text { Leaves.......... } \\
\text { (Sample B)...... }\end{array}$} & $4 \cdot 70$ & 0.0 & Leaves & 3.73 & Present & o. 168 & 3.49 & 5.12 \\
\hline & $4 \cdot 76$ & $\ldots$ & (Sample B) & $3 \cdot 72$ & $\cdots$ & $\cdots$ & . & . \\
\hline & $4 \cdot 71$ & $\cdots$ & $\ldots \ldots$ & 3.74 & $\cdots$ & $\cdots$ & $\cdots$ & . \\
\hline \multirow{3}{*}{$\begin{array}{l}\text { Leaves.......... } \\
\text { (Sample C)...... }\end{array}$} & 4.83 & 0.0 & $\ldots \ldots$ & 3.71 & $\cdots$ & o.I.7I & 3.55 & 5.21 \\
\hline & 4.82 & $\ldots$ & $\ldots \ldots$ & . & $\ldots$ & $\ldots$ & . & . \\
\hline & 4.75 & $\cdots$ & $\cdots$ & . & $\cdots$ & $\cdots$ & . & . \\
\hline \multirow[t]{2}{*}{ Roots.......... } & 2.46 & $\ldots$ & Roots & 2.22 & .. & $\ldots$ & . & . \\
\hline & 2.37 & $\ldots$ & $\ldots \ldots$ & 2.22 & $\ldots$ & $\ldots$ & $\ldots$ & .. \\
\hline \multirow[t]{3}{*}{ (Sample A)..... } & 2.27 & . & (Sample A) & 2.13 & $\ldots$ & $\ldots$ & . . & . \\
\hline & 2.38 & $\cdots$ & $\ldots \ldots$ & $2 . I I$ & $\ldots$ & $\ldots$ & . & . \\
\hline & 2.37 & $\ldots$ & $\ldots .$. & 2.25 & $\ldots$ & .. & $\ldots$ & $\ldots$ \\
\hline \multirow{3}{*}{$\begin{array}{l}\text { Roots............ } \\
\text { (Sample B)...... }\end{array}$} & 2.44 & $\cdots$ & Roots & 2.25 & $\ldots$ & $\ldots$ & $\ldots$ & $\cdots$ \\
\hline & 2.44 & $\ldots$ & (Sample B) & 2.20 & $\ldots$ & $\cdots$ & $\cdots$ & $\cdots$ \\
\hline & $\cdots$ & $\cdots$ & $\ldots \ldots$ & 2.19 & $\ldots$ & $\cdots$ & . & . \\
\hline
\end{tabular}

${ }^{a}$ The proportion of ammoniacal nitrogen in the healthy cabbage was not estinated because of lack of material.

${ }^{1}$ Jodicii, Moulton and Markley, This Journal, 42, 1063 (r920).

${ }^{2} Z$. physiol. Chem., 27, 95 (1899); 29, 47, 136 (1900).

3 Jodidi, S. L., Thus Journat, 32, 396 (rgro); 33, 1226 (I9r r); 34, 94 (rgr2). 
The estimation of the amino acid portion in what constitutes the basic and non-basic nitrogen, as well as the determination of the nitrogen of polypeptides, was effected according to the methods applied to spinach. ${ }^{1}$ Inasmuch as the reaction of amino acids with formaldehyde is reversible in accordance with the equation

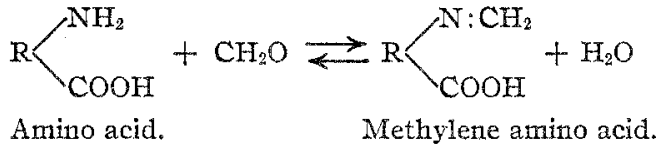

care was taken, on carrying out the formol titration, to add ro more cc. of formaldehyde in each case to make sure that the reaction from left to right was complete. The results obtained are presented in Tables I to IV.

TAbi, II-Showing the Proportion of Nitric Nitrogen in the Cabbage.

\begin{tabular}{|c|c|c|c|c|c|c|c|}
\hline \multirow[b]{2}{*}{$\begin{array}{l}\text { Healthy } \\
\text { cabbage } \\
\text { maaterial. }\end{array}$} & \multicolumn{3}{|c|}{ Nitric nitrogen. } & \multirow[b]{2}{*}{$\begin{array}{c}\text { Diseased } \\
\text { cabbage } \\
\text { material. }\end{array}$} & \multicolumn{3}{|c|}{ Nitric nitrogen. } \\
\hline & $\begin{array}{c}\text { Soluble } \\
\text { nitrogen. } \\
\% .\end{array}$ & $\begin{array}{c}\text { Total } \\
\text { nittogen. } \\
\% .\end{array}$ & $\begin{array}{l}\text { Oven-dried } \\
\text { cabbage. } \\
\% .\end{array}$ & & $\begin{array}{c}\text { Soluble } \\
\text { nitrogen. } \\
\% \% .\end{array}$ & $\begin{array}{c}\text { Total } \\
\text { nitrogen. } \\
\% .\end{array}$ & $\begin{array}{c}\text { Overt-dried } \\
\text { cabbage. } \\
\% .\end{array}$ \\
\hline Leaves. & $\mathrm{I} 2.45$ & 8.48 & $0.4 \mathrm{I}$ & Leaves & 4.08 & 2.06 & 0.08 \\
\hline (rst & 12.45 & 8.48 & $0.4 \pi$ & (Ist sample) & 3.98 & $2.0 \mathrm{r}$ & 0.08 \\
\hline Leaves. & 12.65 & 8.62 & 0.42 & Leaves & 4.53 & 2.29 & 0.09 \\
\hline (and sample) & $\mathbf{x} 2.86$ & 8.76 & 0.42 & (2nd sample) & 4.53 & 2.29 & 0.09 \\
\hline Roots... & $\ldots$ & 6.63 & 0.16 & Roots & . & 4.80 & $0.9 \mathrm{I}$ \\
\hline & $\ldots$ & $6.7 I$ & 0.16 & $\ldots$ & $\ldots$ & 4.76 & 0.10 \\
\hline
\end{tabular}

Table III.-Showing the Proportion of Protein in the Cabbage.

$\overbrace{\begin{array}{c}\text { Fresh } \\ \text { cabbage. } \\ \% .\end{array}}^{\text {Protein nitrogen. }} \begin{gathered}\begin{array}{c}\text { Oven-dried } \\ \text { cabbage. } \\ \% .\end{array} \\ \begin{array}{c}\text { Total } \\ \text { nitrogen. } \\ \% .\end{array}\end{gathered}$

$\frac{\text { Corresponding protein. }}{\begin{array}{c}\text { Fresh } \\ \text { cabbage, } \\ \% \text { Ovandried } \\ \text { cabbaga. } \\ \% .\end{array}}$

Healthy Cabbage Materia1.

\begin{tabular}{|c|c|c|c|c|c|}
\hline \multirow[t]{4}{*}{ I,eaves.......... } & 0.16 & $x .44$ & 29.80 & $I .00$ & 9.00 \\
\hline & 0.16 & 7.43 & 29.62 & I.OO & 8.94 \\
\hline & 0.16 & 1.40 & 29.07 & I.OO & 8.75 \\
\hline & 0.16 & 1.43 & 29.57 & $x .00$ & 8.94 \\
\hline \multirow[t]{4}{*}{ Roots........... } & $\ldots$ & $\mathrm{I} .2 \mathrm{I}$ & $50.4 \mathrm{I}$ & $\ldots$ & $7 \cdot 56$ \\
\hline & $\therefore$ & I. 22 & 51.09 & .. & 7.62 \\
\hline & $\cdots$ & $\mathrm{I} .2 \mathrm{I}$ & $50.4 x$ & $\cdots$ & $7 \cdot 56$ \\
\hline & \multicolumn{5}{|c|}{ Diseased Cabbage Material. } \\
\hline \multirow[t]{4}{*}{ Leaves.......... } & 0.26 & 1.91 & $51 \cdot 16$ & $x .62$ & I I.94 \\
\hline & 0.26 & 1.92 & $51 \cdot 37$ & $x .62$ & 12.00 \\
\hline & 0.26 & $\mathrm{I} .9 \mathrm{~T}$ & 5 1. 16 & $x .62$ & II, 94. \\
\hline & . & I. 43 & 65.05 & $\ldots$ & 8.94 \\
\hline \multirow[t]{2}{*}{ Roots........... } & . & 1.43 & 65.10 & . & 8.94 \\
\hline & .. & 1.42 & $64.7 \mathrm{r}$ & .. & 8.87 \\
\hline
\end{tabular}

'S. L. Jodidi, E. H. Kellogg and R. H. True, J. Agr. Research, 15, 385 (1918): S. P. I. Sörensen, Biochem. Z., 7, 45 (1907). 


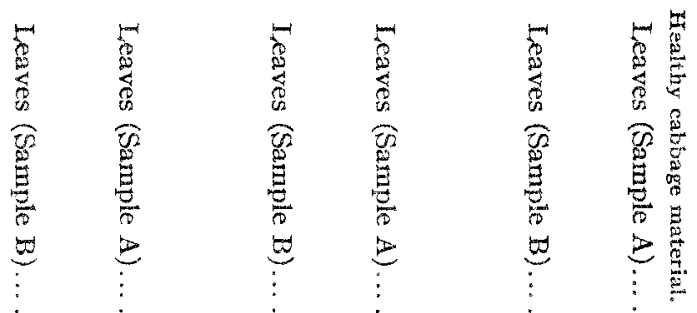

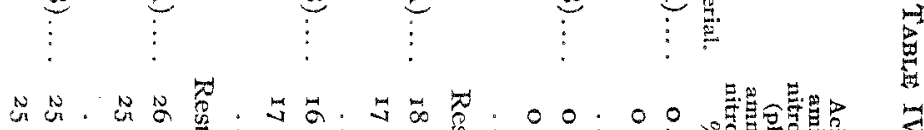

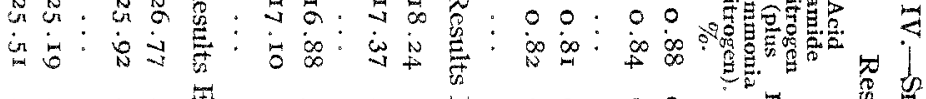

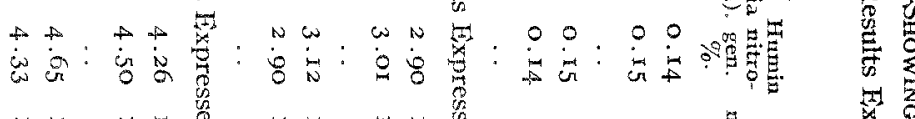

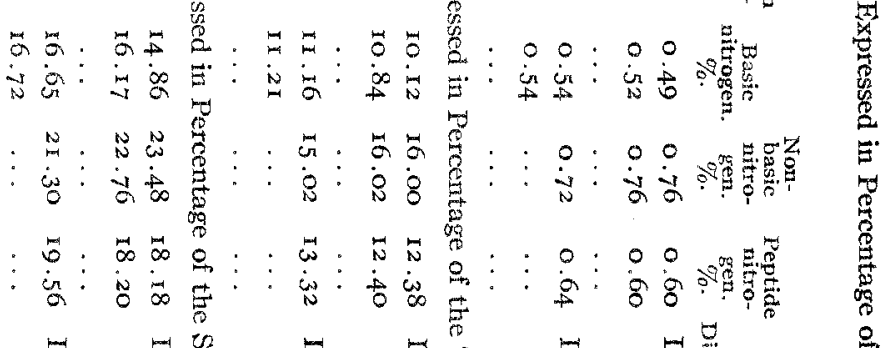

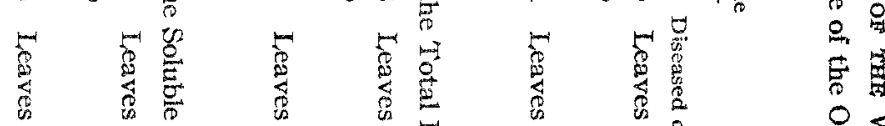

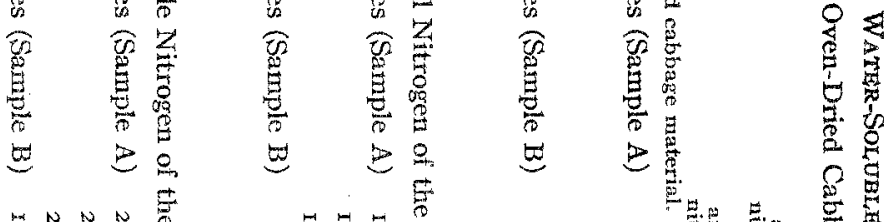

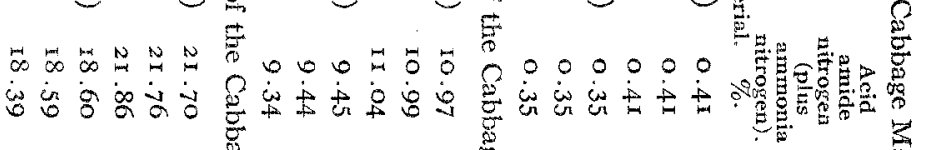

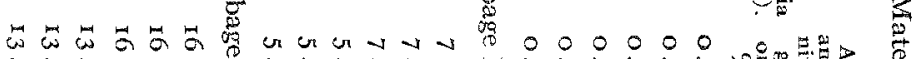

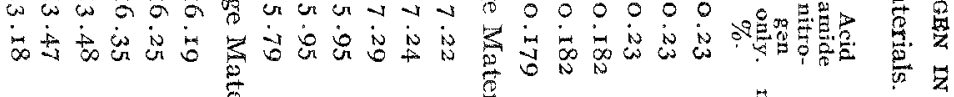

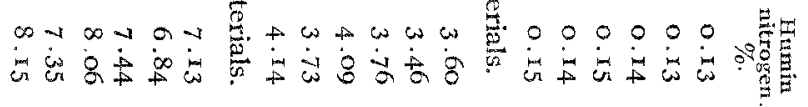

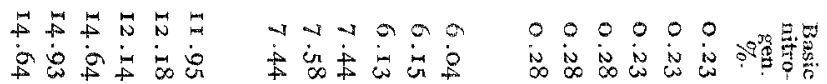

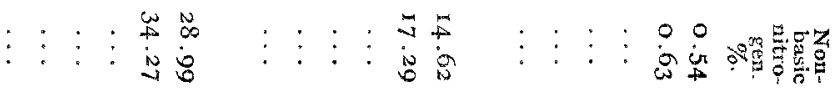

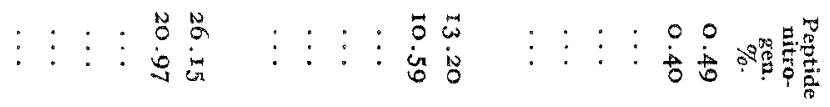




\section{Discussion and Interpretation of Experimental Data.}

Inspection of Table I reveals the fact that under normal physiological conditions the percentage of total nitrogen in the leaves is very much bigher than in the roots (up to I07\%), whereas the difference in the nitrogen content of the diseased leaves and roots, while still high, is essentially smaller (about 70\%). A comparison of the healthy and diseased materials shows that whereas the differences in the nitrogen content of the normal and diseased leaves are considerable, ranging as they do from 27 to $33 \%$, the corresponding differences of the healthy, and diseased roots are comparatively small (from 7 to $9 \%$ ). As to the nitrites, they were found in the diseased materials only. Since the differences mentioned hold true for all of the samples examined, it seems safe to state that the lower nitrogen perceniage and the nitrite content of the affected tissues are characteristic of the cabbage disease under consideration.

By referring to Table II, it will be noticed that when in health the leaves have a higher percentage of nitric nitrogen than the roots, whereas under pathological conditions the reverse is the case. How are these facts to be interpreted? While, absolutely, the percentage of nitric nitrogen in the diseased leaves and roots is smaller than in the corresponding healthy tissues, the nitrate ratio of the diseased roots to healthy roots is relatively very much greater than the nitrate ratio of the diseased leaves to healthy leaves. This can only be taken to mean that loss of nitrates occurs in the diseased cabbage, the loss taking place in a higher degree in the leaves than it does in the roots. The very striking difference in the nitrate content of all diseased tissues, on the one hand, and the healthy on the other, does not seem to leave any doubt but that the lower nitrate content of the diseased plants is another characteristic feature of the cabbage disease.

A glance at Table III shows that normally the cabbage leaves are richer in protein and protein nitrogen than the roots when calculated to the oven-dried cabbage. The apparent exception in the case of the total nitrogen may be explained by the fact that the percentage of total nitrogen is very much higher in the leaves (Table I) to which the protein nitrogen was calculated. These relations hold good also for the diseased cabbage. When, however, the healthy tissues are compared with the diseased, it is seen that the latter in each and every case have a higher protein and protein nitrogen content. It is easy to see why the latter is higher in the diseased plants than in the healthy when calculated on the total nitrogen, which is considerably lower in the diseased plants (Table I). Just why this content is also higher in the diseased tissues when related to the fresh and oven-dried cabbage needs further elucidation in view of the close relation of the proteins to the life functions of the plants. That 
the diseased tissues have a comparatively higher protein content seems to indicate clearly that no loss of protein nitrogen is caused by the disease. This is probably due to the fact that proteins, belonging practically to the least soluble among the nitrogenous compounds occurring in plants, offer the least points of attack by the nitrous acid, as was pointed out elsewhere. ${ }^{1}$ Coupled with this is the more or less stunted condition of the diseased plants in which, while the proteins remain intact, other compounds such as nitrates, acid amides, amino acids, etc., are destroyed, at least in part, with the result that the protein in the diseased plants is calculated on a smaller quantity of tissue. Another interpretation suggests itself from a teleological standpoint. The diseased plants having lost a large portion of their nitrogen are making an effort to make good that loss. They accomplish it by converting whatever nitrogen has remained in them, into the highest and most useful form of nitrogen, namely, into proteins.

By examining Table IV it is evident that the proportion of acid amide, basic and non-basic nitrogen is higher in the healthy cabbage than in the diseased, the only exception being the percentage of non-basic nitrogen when calculated to the soluble nitrogen. This may be ascribed to the considerably higher protein nitrogen content of the diseased plants (Table III), and hence to their correspondingly lower soluble nitrogen content on which the non-basic nitrogen was calculated. Inastnuch as the differences noticed hold good for all of the materials investigated it seems justified to state that a lower acid amide, basic and non-basic nitrogen conient of the diseased tissues is also characteristic of the cabbage disease.

As to the peptide nitrogen, the results, which are not conspicuous enough and run, moreover, in opposite directions, do not permit of any definite conclusion.

The proportion of humin nitrogen appears to be higher in the diseased cabbage plants than in the normal ones. Since, however, in Hausmann's nitrogen distribution method as applied here, the conditions of hydrolysis ${ }^{2}$ as well as of distillation of the hydrolyzed and evaporated cabbage extracts with magnesium oxide ${ }^{3}$ were identical, the amount of humin attributable to the acid hydrolysis must have been the same in the case of the vatious cabbage tissues, healthy and diseased. Hence, the larger percentage of humin nitrogen in the affected plants seems to be also characteristic of the cabbage disease and may perhaps have something to do with the change of color from green to metallic in the diseased tissues.

'Jodidi, Moulton and Markley, This Journal, 42, I069 (1920).

2 Ordinarily the solutions obtained by repeated extraction of the cabbage materials with boiling hot, ammonia-free water were treated with enough conc. hydrochloric acid to make a $20 \%$ acid and boiled for Io hours, using a reflux condenser.

${ }^{3}$ Jodidi, S. L. and S. C. Moulton, Tris Journal, 4I, I526 (igig). 


\section{Nature of the Cabbage Disease.}

Of plant diseases those which are brought about by the activity of microörganisms (bacteria, fungi) are the best known. They are firmly established not only because the organisms causing the disease have been isolated from the diseased tissues and identified, but also because, in a great many cases, the pure cultures of the organisms in question when inoculated into healthy plants produced a disease identical with that of the affected plants from which the pure cultures had been obtained. As an example of this type of (bacterial) diseases of which more than a hundred are known it may suffice to mention crown gall and cancer in plants caused by Bacterium tumefaciens and now so well known through the remarkable work of Snith ${ }^{1}$ and his collaborators. To another type belong the so-called virus diseases the cause of which remains unknown, since attempts to isolate microörganisms from and to associate them with affected tissues thus far have proved futile. As examples of this type the mosaic disease of tobacco ${ }^{2}$ (Nicotiana tabacum) and spinach $^{3}$ (Spinacia oleracea) may be cited, in both of which the disease may be communicated to normal plants by virus-bearing aphids or by inoculating the infective principle into healthy tissues.

So far as the cabbage disease is concerned, it is perfectly true that preliminary experiments looking to the establishment of its infective nature have thus far led to negative results. However, judging from the striking similarity of the analytical evidence presented with regard to the various nitrogenous compounds occurring in healthy and blighted spinach plants, on the one hand, and in normal and diseased cabbage plants on the other, and taking into consideration that spinach blight belongs to the type of mosaic diseases, it appears logical to relate the cabbage disease caused by denitrification to the latter type. So strikingly similar are the figures characteristic of diseased tissues in cabbage and spinach that it seems worth while to arrange the data on spinach in tabular form for the sake of convenient comparison (Table V). To be sure, when we compare Tables I, II, III and IV, on the one side, and Table V on the other, we find considerable distinctions, $e . g$., in the nitrogen of nitrates, acid amides, proteins present in the cabbage and spinach plants under normal conditions. But the features characteristic of the mosaic disease of spinach, especially the smaller percentage of total, nitrate, acid amide, basic and non-basic nitrogen of the affected tissues hold good also for cabbage in practically every particular.

1 Erwin F. Smith, J. Cancer Research, 1, 23x (1916); J. Agr. Research, 6, 179 (1916); 8, 165 (I917); also Bur. Plant Ind., Bull. 213 and 255 .

${ }^{2}$ H. A. Allard, $J$. Agr. Research, 6, 649 (r916); 10, 615 (1917).

3 This Jours. AL, 42, IO6I (r920); J. Agr. Research, I4, I (1918). 


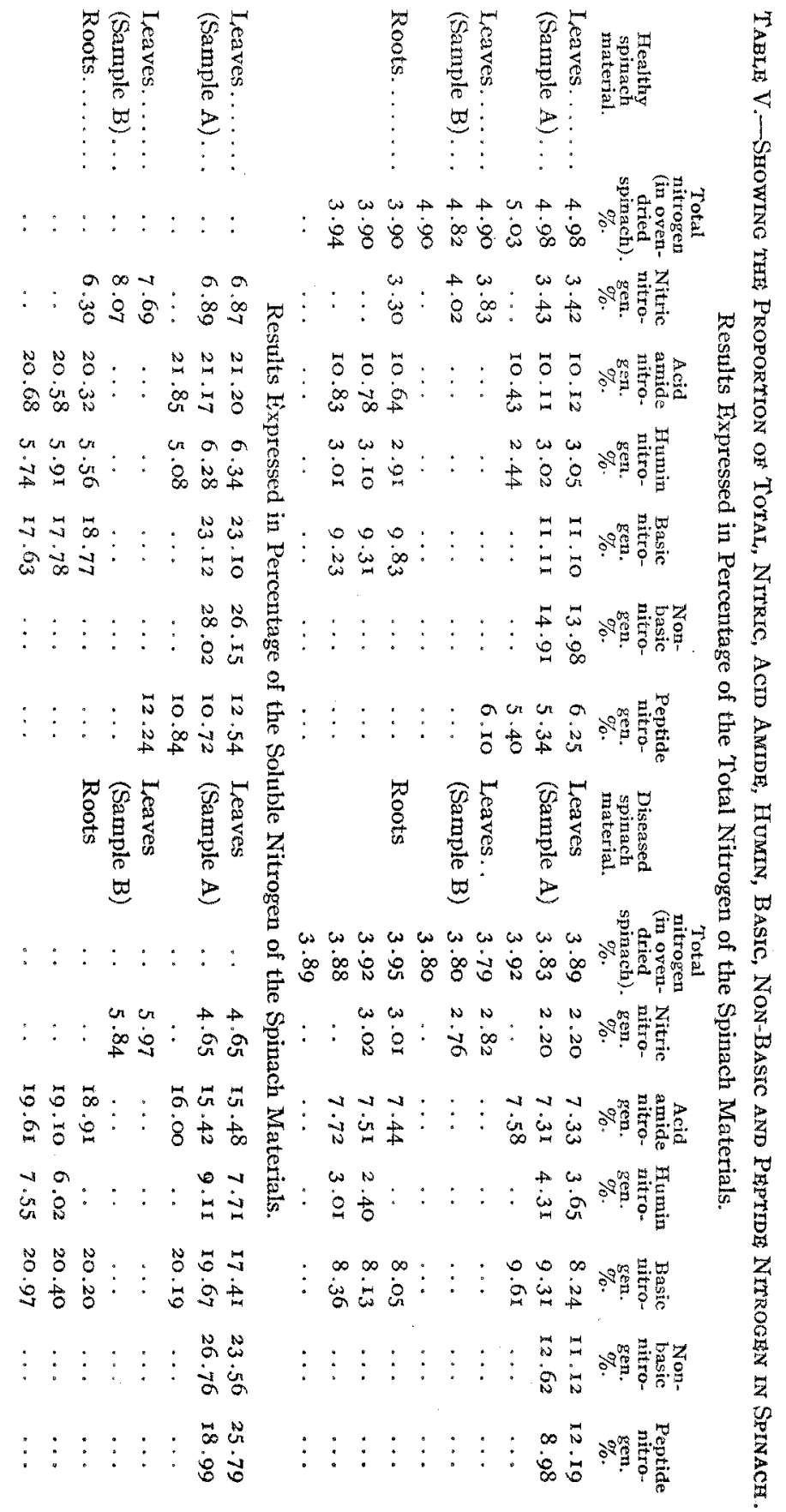




\section{Summary and Conclusions.}

The cabbage disease investigated is characterized by denitrification taking place in the affected tissues, whereby the nitrates are in part reduced to ammonia which is lost as such, and in part to nitrites which, reacting on the amino groups of the various organic compounds-acid amides, amino acids, etc.,-bring about the elimination of elementary nitrogen. This is the reason why diseased cabbage tissues have a smaller proportion of total, nitrate, acid amide, di-amino and mono-amino nitrogen, nitrites occurring in diseased tissues only.

Denitrification occurs in affected cabbage leaves in a very much higher degree than it does in the roots. This follows conclusively from the fact that while the differences in total, nitrate nitrogen, etc., of healthy and diseased leaves are large, those of normal and affected roots are considerably smaller.

There is a higher proportion of protein and protein nitrogen in the diseased cabbage tissues than in the normal. This is interpreted to mean that the affected plants possess the ability of building up proteins from the lower nitrogenous compounds, and that the protein nitrogen is not attacked by the nitrous acid, the protein and protein nitrogen being related in the diseased plants to a smaller nitrogen content and a smaller quantity of tissue.

Loss of nitrogen in the affected cabbage tissues is in itself an explanation of the cabbage disease. Thus, e.g., one of its conspicuous characteristics, the dwarfing of the plants, is easily understood when we bear in mind that the nitrogenous compounds, such as acid amides, amino acids, and others, which are partly lost through denitrification, are the very materials out of which the plant is building up its tissues.

It seems not out of the question that the change of color from green to metallic in the diseased tissues may be due to a larger proportion of humin. present, the lack of nitrogen perhaps coming also into play.

In the healthy cabbage samples the nitrogen is made up, in round fig. ures, of $30 \%$ protein nitrogen, $7 \%$ di-amino ${ }^{1}$ nitrogen, $10 \%$ mono-amino nitrogen, and $\mathrm{r}_{3} \%$ peptide nitrogen, which means that at least $60 \%$ of the nitrogen compounds present in cabbage have direct nutritive value.

Under normal conditions the cabbage leaves have a higher percentage of total and nitrate nitrogen than the roots, which was shown to hold true also for the spinach ${ }^{2}$ plant.

Wasmingtos, D. C.

T The cabbage nitrogen consists of $10 \%$ and $16 \%$ of basic and non-basic nitrogen, respectively (Table IV), of which $63.14 \%$ and $64.23 \%$ were found by formal titration to represent diamino and mono-amino nitrogen, respectively.

2 Loc. cit. 